\title{
Removal of Remazol Red from Textile Waste Water Using Treated Sawdust - An Effective Way of Effluent Treatment
}

\author{
Nargish Jahan Ara, Md. Abu Hasan, Mohammad Arifur Rahman, Md. Abdus Salam, \\ Abdus Salam and A. M. Shafiqul Alam
}

Department of Chemistry, University of Dhaka, Dhaka-1000, Bangladesh

\begin{abstract}
Activated carbon prepared from sawdust is endeavored as adsorbent for the removal of reactive dye, namely Remazol Red (RR) from aqueous media. The adsorption of RR has been studied onto activated sawdust at various particle size, adsorbent dose, temperature and $\mathrm{pH}$ values. The adsorptions of the above mentioned dye were designed for the Langmuir and Freundlich Isotherms. Pseudo first and second order kinetic models were used to calculate the amount adsorbed at equilibrium $\left(\mathrm{q}_{\mathrm{e}}\right)$. The calculated values of $\mathrm{q}_{\mathrm{e}}$ for pseudo-second order equation were found to be in good agreement with those of experimental values. The monolayer capacity $\left(\mathrm{q}_{\mathrm{m}}\right)$ for treated sawdust $\left(8.00 \mathrm{mg} \mathrm{g}^{-1}\right)$ is greater than commercial charcoal $\left(0.074 \mathrm{mg} \mathrm{g}^{-1}\right)$. It is established that treated sawdust has been used as a better adsorbent for the removal of RR as compared to commercial charcoal. This process may eventually be used to get industrial waste free purified water.
\end{abstract}

Key words: Sawdust, Remazol Red, Adsorption Isotherm, Adsorption Kinetics.

\section{Introduction}

Industrial effluents are one of the major pollutants of water. Many dyes are carcinogenic and affect the life of aquatic organisms (Baughman et al., 1998; Hassan et al., 2009). Removal of azo dyes from the effluent generated by textile industries is rather difficult. Azo dyes represent a major class of synthetic colorants that are both mutagenic and carcinogenic (Waghmode et al., 2012). Reactive dyes are extensively used in textile industry and due to their large size they have high affinity to bind with cellulosic fiber. The worldwide annual growth rates of reactive dyes are four times as much as for conventional dyes (Zollinger, 2003). Vinyl sulfone dyes are a class of reactive dyes effectively used for cotton, silk and wool. They are also known as remazol dyes after the trademarked name under which they were first introduced. Vinyl sulfone dyes are less reactive than other dyes and therefore major part of these dyes remains in dyeing bath or drained off as industrial effluents. It has been reported that up to $30 \%$ of the used dyestuff remains in the spent dye-bath after the dying process (Ozacar et al., 2005). Presence of such dyes in effluents causes a lot of pollution in water. Various challenges have been made to remove these harmful dyes from industrial wastes (Ho et al., 2005; Mohanty et al. 2006; Sousa et al., 2012).
Adsorption is one of the cheapest and most effective techniques (Cotoruelo et al., 2007; Dee et al., 2006). Different adsorbents are used for the removal of dyes from aqueous solutions such as alumina, crushed bricks, peat, sand, charcoal bentonite, silica, apricot etc ( $\mathrm{Hu}$ et al., 2006; Jain et al., 2009; Mon, 2004; Senthilkumaa et al., 2006 ). The most widely used adsorbent for the removal of dyes are charcoal prepared from saw dust which is inexpensive and easily available. Therefore, the interest is growing to find out an alternative adsorbent to commercial charcoal.

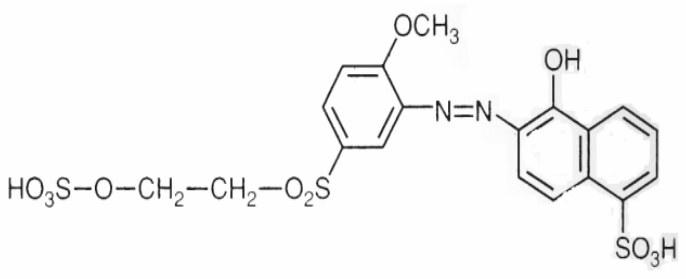

Figure 1. Structure of Remazol Red.

The objective of this work is to study the feasibility of activated sawdust as alternate adsorbents to commercial charcoal (Ahmadpour et al., 1997; Arivoli et al., 2010) for the removal of Remazol Red (RR) (Figure 1). The adsorption results of RR onto saw dust are also compared with that of commercial charcoal. 


\section{Materials and Methods}

Preparation of activated charcoal: There are two different methods for the preparation of activated carbon: physical activation and chemical activation (Ho et al., 2005). In comparison to physical activation, chemical activation provides a number of advantages. The process of dye removal was applied in batch mode. Adsorption experiments were performed by suspending sawdust in the effluent and analyzing the supernatant by spectroscopic method.

Sawdust (Shegun, Tectona grandis) was collected from nearby Sawmill (Rampura, Dhaka, Bangladesh). This was washed with double distilled water to remove water-soluble impurities and surface-adhered particles. Then the adsorbent was oven-dried at $60^{\circ} \mathrm{C}$ to remove the moisture and other volatile impurities. Then, part of the dried sawdust was soaked in concentrated $\mathrm{H}_{2} \mathrm{SO}_{4}$ in an amount sufficient to cover the material completely, agitated at $120 \mathrm{rpm}$ in a shaking incubator for $30 \mathrm{~min}$, and then left for $2 \mathrm{~h}$. After being mixed, the slurry was subjected to vacuum-drying at $100^{\circ} \mathrm{C}$ for $24 \mathrm{~h}$. Chemical activation of the sawdust was performed with $\mathrm{ZnCl}_{2}$. Ten grams of sawdust was mixed well with $100 \mathrm{ml}$ of $10 \%$ of $\mathrm{ZnCl}_{2}$ solution. The mixing was performed at $50^{\circ} \mathrm{C}$ for 1 h. After mixing, the slurry was subjected to vacuumdrying at $100^{\circ} \mathrm{C}$ for $24 \mathrm{~h}$ (Mohanty et al., 2006; Ahmadpour et al., 1997).

The resulting impregnated solids was placed in a stainless steel tubular reactor and heated $\left(5^{\circ} \mathrm{C} \mathrm{min}^{-1}\right)$ to a temperature of $300^{\circ} \mathrm{C}$ under nitrogen flow at a rate of 150 $\mathrm{cm}^{3} \mathrm{~min}^{-1}$ at STP for $1 \mathrm{~h}$. Nitrogen entering the reactor was first heated to $250-300^{\circ} \mathrm{C}$ in a preheater. The products were washed sequentially with $0.5 \mathrm{M} \mathrm{HCI}$, hot water and finally with cold distilled water to remove residual organic and mineral materials and then dried at $110^{\circ} \mathrm{C}$. In all experiments, the heating rate and nitrogen flow were kept constant.

Preparation of dye solution: Remazol Red (RR) was used in the experiment. It is a reactive dye supplied by Dye Star Ltd., Dhaka, Bangladesh. This dye form covalent bond with the fiber, usually cotton, although itis used to a small extent on wool and nylon. This class of dyes first introduced commercially in 1956, made it possible to achieve extremely high washing fastness properties by relatively simple dyeing methods. A stock solution of
$1000 \mathrm{ppm}$ RR was prepared by dissolving appropriate amount of dye in water. The required concentration was prepared for the various steps of the investigation by dilution.

Study of batch adsorption process: Equilibrium isotherms for adsorption onto the selected carbons determined by using $1 \mathrm{~g}$ of adsorbent per $50 \mathrm{ml}$ of aqueous solution for initial dye concentrations in the range of 50$200 \mathrm{ppm}$. For these experiments, the bottles were shaken at constant temperature $\left(25^{\circ} \mathrm{C}\right)$ and agitation speed $(120$ rpm), for the minimum contact time required to attain equilibrium, as determined from the kinetic measurements. The effectiveness of the treatment was evaluated by measuring concentration by UV-Visible spectroscopic method at $541.5 \mathrm{~nm}$.

The influence of $\mathrm{pH}$ was studied by adjusting the reaction mixture to different initial $\mathrm{pH}$ values and analyzing the residual color at the equilibrium contact time. The $\mathrm{pH}$ values were adjusted with dilute sulfuric acid and sodium hydroxide solutions. Then the percentage of dye removal was calculated by,

$\mathrm{R}=\frac{\left(C_{o}-C_{e}\right)}{C o} \times 100 \%$

The amount of dye adsorbed onto the activated carbons, $\mathrm{q}_{\mathrm{e}}(\mathrm{mg} / \mathrm{g})$, was calculated according to:

$q_{e}=\frac{\left(C_{o}-C_{e}\right) V}{W}$

where $C_{0}$ and $C_{e}$ are the initial and the final dye concentrations $(\mathrm{mg} / \mathrm{l})$, respectively, and $W$ is the amount of adsorbent $(\mathrm{g}), V$ is the volume of the solution (L).

\section{Results and Discussion}

The physical properties of treated sawdust: The physical properties of the treated sawdust have been shown in the Table 1. From the table it is found that the BET surface area (Rabolli et al., 2010) is $5.69 \mathrm{~m}^{2} / \mathrm{g}$ and the average pore diameter is $99.60 \mathrm{~A}^{0}$. The point of zero charge (pzc) of the above mentioned adsorbent is 5.5.

Optimization of contact time: The contact time between dye and adsorbent is of significant importance in waste water treatment by adsorption methods. A rapid removal of pollutants and establishment of equilibrium in a short period signifies the efficacy of the adsorbent. The effect of shaking time for the adsorption of dye onto charcoal prepared from sawdust was determined at $25^{\circ} \mathrm{C}$. 
The fixed concentration of RR was shaken after adding $1 \mathrm{~g}$ of adsorbent in each time. Color removal was rapid at initial stage but decreased with the increase of time (Fig. 2). Initially rapid increase was due to the presence of large number of vacant site and with the passage of time, number of active sites decreased which were responsible for the reduction of adsorption rate. The optimum contact time was observed 12 hours for all the adsorbents.

Table 1. Physical properties of treated sawdust.

\begin{tabular}{lr}
\hline Properties & value \\
\hline Particle size $(\mu \mathrm{m})$ & $<140$ \\
BET surface area $\left(\mathrm{m}^{2} / \mathrm{g}\right)$ & 5.69 \\
Average pore diameter $\left(\mathrm{A}^{0}\right)$ & 99.60 \\
Micro pore volume $(\mathrm{cc} / \mathrm{g})$ & 0.014 \\
Micro pore area $\left(\mathrm{m}^{2} / \mathrm{g}\right)$ & 2.37 \\
Bulk density $(\mathrm{g} / \mathrm{ml})$ & 0.84 \\
pzc & 5.5 \\
\hline
\end{tabular}

Optimization of adsorbent amount: For optimizing the amount of adsorbents,experiments were performed using $50 \mathrm{ml}$ aqueous solution of RR and was shaken for 120 minutes after adding different amount of adsorbents (0.5$3.0 \mathrm{~g})$. Absorbance of the filtrate was noted using spectrophotometer at $\lambda_{\text {max }}$ of the dye. It was observed that adsorption of dye increased with the increase of the amount of adsorbents and then attained constant value at equilibrium (Fig. 3). The optimum amount was found to be $1.0 \mathrm{~g}$ which was used for all subsequent adsorption studies.

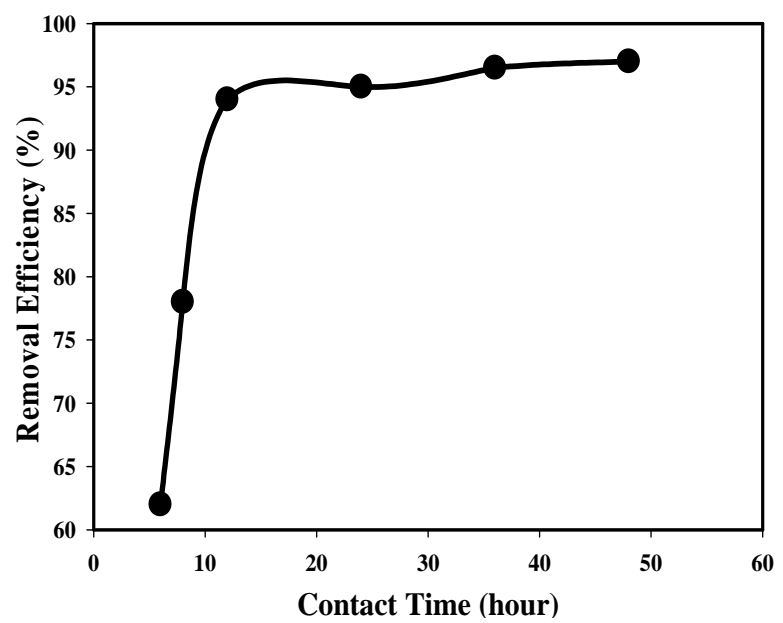

Figure 2. Effect of contact time on the removal of RR. Particle size: $140 \mu \mathrm{m}$; Adsorbent amount: $1.0 \mathrm{~g}$; Initial conc.: $50 \mathrm{mg} / \mathrm{l}$; Initial volume: $50 \mathrm{ml}$; $\mathrm{pH}$ : 7.0; Temp.: $25^{\circ} \mathrm{C}$.

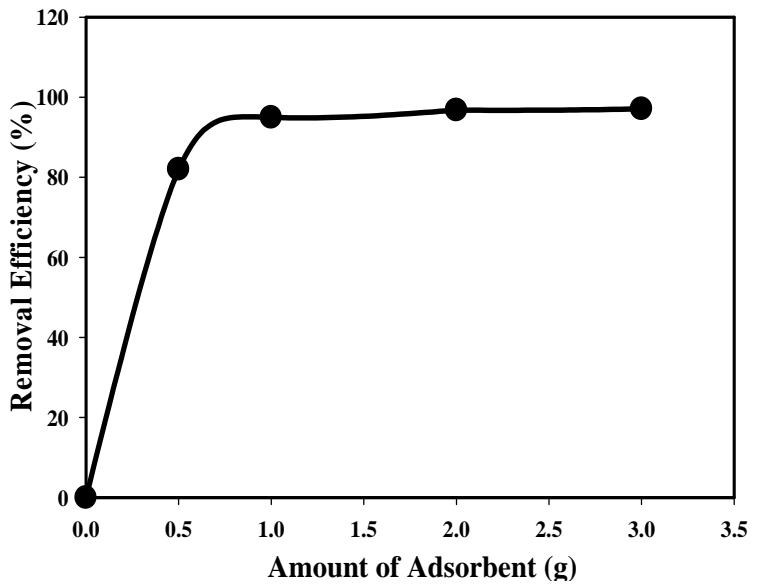

Figure 3. Effect of adsorbent amount on the removal of RR. Particle size: $140 \mu \mathrm{m}$; Initial concentration: $50 \mathrm{mg} / \mathrm{l}$; Initial volume: $50 \mathrm{ml}$; $\mathrm{pH}$ : 7.0; Contact time: 12 hours; Temp.: $25^{\circ} \mathrm{C}$.

Influence of initial $\mathrm{pH}$ : Hydrogen and hydroxy1 ions are usually adsorbed quite strongly on the surface of the adsorbents due to their smaller size as compared to the dye molecules and therefore adsorption of other ions is affected by $\mathrm{pH}$ of the solution. The $\mathrm{pH}$ primarily affects the degree of ionization of the dye as well as surface properties of the adsorbents. Adsorption of RR decreased with increase in $\mathrm{pH}$ (Figure 3). This can be explained on the basis that positively charged surface is formed on the adsorbents at lower $\mathrm{pH}$ due to adsorption of hydrogen ions on the surface of adsorbents.

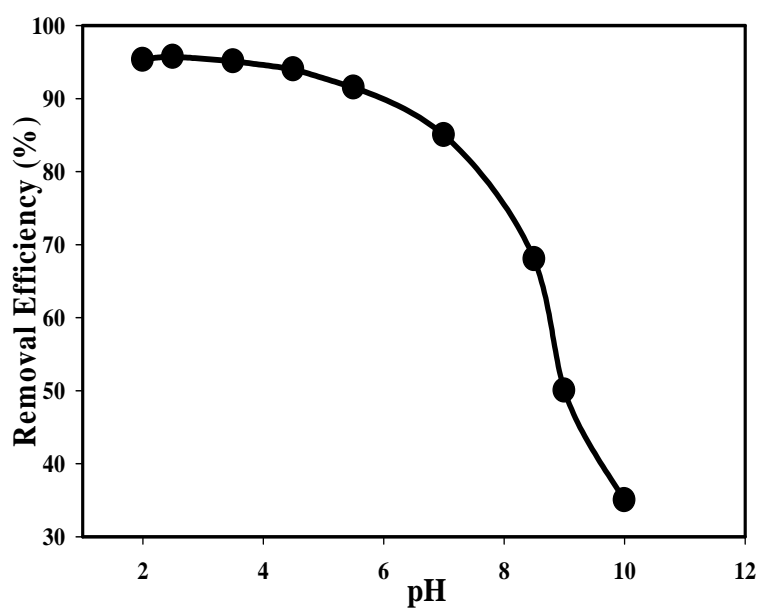

Figure 3. Effect of $\mathrm{pH}$ on the adsorption capacity of saw dust for Remazol red at $25^{\circ} \mathrm{C}$. 
It has been reported that the positively charged ions prefer to adsorb at higher $\mathrm{pH}$ value and negatively charged ions prefer lower $\mathrm{pH}$. As $\mathrm{pH}$ of the system increases, number of positively charged site on the surface of adsorbents decreases. As the dye is in dissociated form the anion (Equation 3) and as a result adsorption of dye decreased at higher $\mathrm{pH}$ values.

$$
\mathrm{ASO}_{2} \mathrm{Na} \stackrel{\mathrm{H}^{+}-\mathrm{OH}^{-}}{\longleftrightarrow} \mathrm{ASO}_{2}^{-} \mathrm{Na}^{+}
$$

The decrease in the amount of dye adsorbed on surface of the adsorbents with increase in $\mathrm{pH}$ is in good agreement with the data reported earlier (Ahmadpour et al., 1997)

Adsorption isotherms: The adsorption isotherms of RR on sawdust were found to be L-type in each case (Ho et al., 2005). The initial sharp rise in the degree of adsorption with increasing dye concentration is due to the availability of higher adsorption sites on the surface of the adsorbents. When the concentration of dye solution increases, adsorption sites are decreased. As a result, the dye molecules find difficulty to access the remaining vacant surface. Adsorption of RR is found to be slightly increased with increase in temperature then remain almost constant (Figure 4). This indicates that desorption process is more favorable at lower temperature and is expected to be an endothermic process.

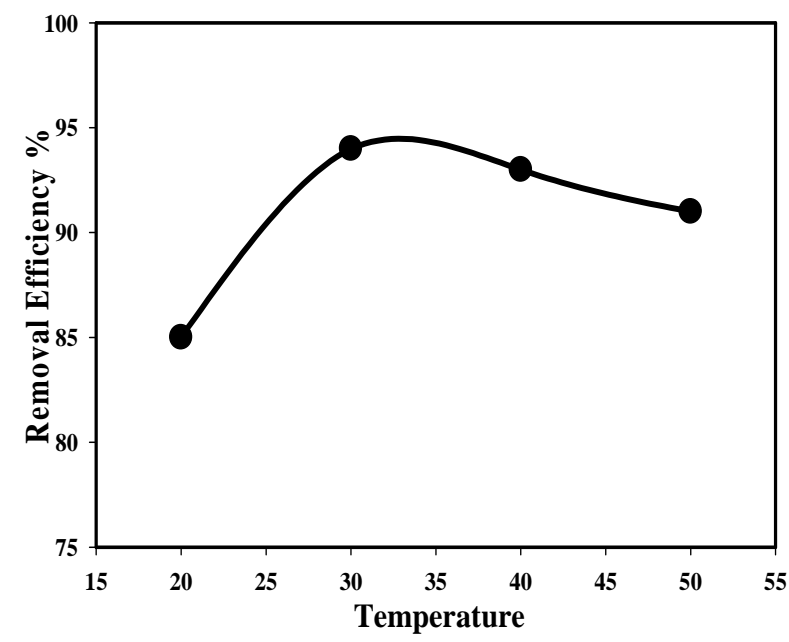

Figure 4. Effect of temperature on the removal of RR. Particle size: $140 \mu \mathrm{m}$; Adsorbent amount: $1.0 \mathrm{~g}$; Initial conc.: 50 $\mathrm{mg} / \mathrm{L}$; Initial volume: $50 \mathrm{ml}$; $\mathrm{pH}$ : 7; Contact time: 12 hours.
Adsorption data for Remazol Red onto activated sawdust was fitted to the linear forms of Freundlich (4) and Langmuir (5) equations

$\log \left(q_{e}\right)=\frac{1}{n} \log \left(C_{e}\right)+\log \left(K_{F}\right)$

Where $\mathrm{q}_{\mathrm{e}}(\mathrm{mg} / \mathrm{g})$ is the amount adsorbed per unit mass of the adsorbent, $\mathrm{C}_{\mathrm{e}}$ is the equilibrium concentration, $\mathrm{K}_{\mathrm{F}}$ and $1 / n$ are constants, being indicative of the extent of adsorption and degree of non-linearity between solution concentration and amount of dye adsorbed respectively.

From Freundlich plot (Figure 5), the constants $\mathrm{K}_{\mathrm{F}}$ and $\mathrm{n}$ are calculated from the intercepts and slopes of linear plots of $\log \left(\mathrm{q}_{\mathrm{e}}\right)$ versus $\log \left(\mathrm{C}_{\mathrm{e}}\right)$, respectively and their values are given in Table 2. If $\mathrm{n}=1$, adsorption is homogeneous and there is no interaction between the adsorbed species. If $\mathrm{n}<1$, the adsorption is unfavorable and if $\mathrm{n}>1$, then the adsorption is favorable. In present studies, we have found that $\mathrm{n}$ is greater than unity for the given adsorbents which indicates that adsorption is favorable. It has also been reported that the value of $\mathrm{K}_{\mathrm{F}}$ gives rough estimation about the degree of adsorption. In the present studies it was observed that the value of $\mathrm{K}_{\mathrm{F}}$ for the adsorption of RR onto saw dust $\left(1.71 \mathrm{mgg}^{-1}\right)$ is greater than those for charcoal (5.91 $\mathrm{mg} \mathrm{g}^{-1}$ ) (Table 2). Greater value of $\mathrm{K}_{\mathrm{F}}$ for activated sawdust reflects that it is better adsorbent for the removal of RR than commercial charcoal.

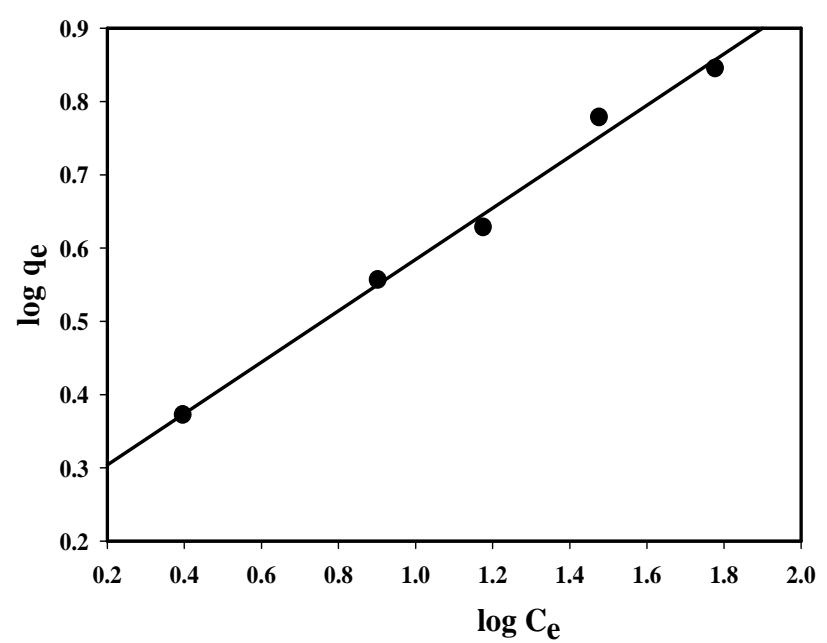

Figure 5. Freundlich isotherms of Remazol Red on saw dust at $25^{\circ} \mathrm{C}$. 
Table 2. Freundlich parameters for Remazol red on Sawdust and commercial charcoal at $25^{\circ} \mathrm{C}$.

\begin{tabular}{lrrr}
\hline Adsorbents & $\mathrm{n}$ & $\mathrm{K}_{\mathrm{F}}$ & $\mathrm{R}^{2}$ \\
\hline Prepared activated saw dust & 2.85 & 1.71 & 0.991 \\
\hline $\begin{array}{l}\text { Commercial activated } \\
\text { carbon }\end{array}$ & 1.79 & 5.91 & 0.998 \\
\hline
\end{tabular}

Langmuir equation is given as

$$
\frac{\mathrm{C}_{\mathrm{e}}}{\mathrm{q}_{\mathrm{e}}}=\frac{1}{\mathrm{q}_{\mathrm{m}} \mathrm{K}_{\mathrm{a}}}+\frac{\mathrm{C}_{\mathrm{e}}}{\mathrm{q}_{\mathrm{m}}}
$$

A plot of $\mathrm{C}_{\mathrm{e}} / \mathrm{q}_{\mathrm{e}}$ versus $\mathrm{C}_{\mathrm{e}}$ should indicate a straight line of slope $1 / \mathrm{q}_{\mathrm{m}}$ and an intercept of $1 /\left(K_{a} \mathrm{q}_{\mathrm{m}}\right)$, where $C_{e}$ is the equilibrium concentration $\left(\mathrm{mg} / \mathrm{dm}^{3}\right)$, $q_{e}$ is the amount of dye sorbed $(\mathrm{mg} / \mathrm{g}), \mathrm{q}_{\mathrm{m}}$ is $\mathrm{q}_{\mathrm{e}}$ for a complete monolayer $(\mathrm{mg} / \mathrm{g})$, and $K_{a}$ is the sorption equilibrium constant $\left(\mathrm{dm}^{3} / \mathrm{mg}\right)$. The essential characteristics of Langmuir eqn. can be expressed in terms of separation factor $\mathrm{R}_{\mathrm{L}}$ (Rao et al., 2008),

Where $\mathrm{R}_{\mathrm{L}}=1 /\left(1+\mathrm{K}_{\mathrm{a}} \cdot \mathrm{Co}\right)$

$* \mathrm{R}_{\mathrm{L}}>1$; Unfavorable.

$* 0<\mathrm{R}_{\mathrm{L}}<1$; Favorable.

$* \mathrm{R}_{\mathrm{L}}=1$; Linear.

* $\mathrm{R}_{\mathrm{L}}=0$; Irreversible.

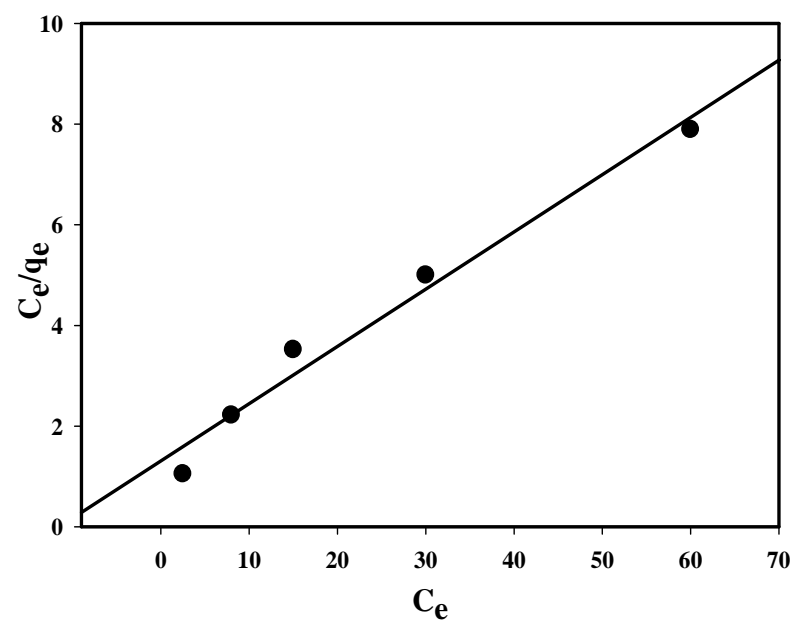

Figure 6. Langmuir isotherms of RemazolRed on sawdust at $25^{\circ} \mathrm{C}$.
Table 3. Langmuir parameters and separation factor $R_{L}$ for adsorption of RR on treated sawdust.

\begin{tabular}{lllll}
\hline Adsorbent & $\begin{array}{l}\mathrm{K}_{\mathrm{a}} / \\
\mathrm{dm}^{3} \mathrm{mg}^{-1}\end{array}$ & $\begin{array}{l}\mathrm{q}_{\mathrm{m}} / \\
\mathrm{mgg}^{-1}\end{array}$ & $\mathrm{R}^{2}$ & $\mathrm{R}_{\mathrm{L}}$ \\
\hline $\begin{array}{l}\text { Prepared } \\
\text { activated saw dust }\end{array}$ & 0.105 & 8.00 & 0.988 & 0.045 \\
$\begin{array}{l}\text { Commercial } \\
\text { activated carbon }\end{array}$ & 7974.8 & 0.074 & 0.9448 & \\
\hline
\end{tabular}

Adsorption kinetics: In order to investigate the adsorption processes of Remazol Red onto sawdust two kinetic models were used. Pseudo-first order kinetic equation is given as (Ho et al., 2005):

$$
\log \left(\mathrm{q}_{\mathrm{e}}-\mathrm{q}_{\mathrm{t}}\right)=\log \mathrm{q}_{\mathrm{e}} \frac{\mathrm{k}_{1}}{1.202} \mathrm{t}
$$

Where, $\mathrm{q}_{\mathrm{t}}$ is the amount of dye adsorbed at time $\mathrm{t}$ $\left(\mathrm{mgg}^{-1}\right), \mathrm{q}_{\mathrm{e}}$ is the amount adsorbed at equilibrium $\left(\mathrm{mg} \mathrm{g}^{-1}\right)$, $\mathrm{k}_{1}$ is the pseudo-first order rate constant $\left(\mathrm{min}^{-1}\right)$ and $\mathrm{t}$ is the contact time ( $\mathrm{min})$.

Values of the constants, $\mathrm{k}_{1}$ and $\mathrm{q}_{\mathrm{e}}$ for the adsorption of dye on the adsorbents were determined from the slopes and intercepts of the plots $\log \left(\mathrm{q}_{\mathrm{e}}-\mathrm{q}_{\mathrm{t}}\right)$ against $\mathrm{t}$, respectively and their values are given in Table 4.

Pseudo-second order model can be represented in the following form

$$
\frac{\mathrm{t}}{\mathrm{q}_{\mathrm{t}}}=\frac{1}{\mathrm{k}_{2}\left(\mathrm{q}_{\mathrm{e}}\right)^{2}}+\frac{\mathrm{C}_{\mathrm{e}}}{\mathrm{q}_{\mathrm{t}}} \mathrm{t}
$$

Where, $\mathrm{k}_{2}$ is the Pseudo-second order rate constant $\left(\mathrm{gmg}^{-1} \min ^{-1}\right)$. The values of the $\mathrm{q}_{\mathrm{e}}$ and $\mathrm{k}_{2}$ were determined by potting a graph between $\mathrm{t} / \mathrm{qt}$ and time.

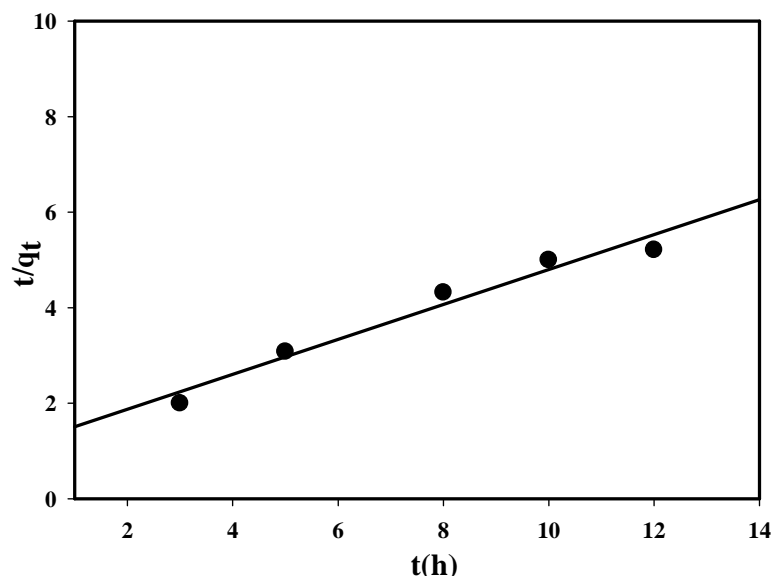

Figure 7. Pseudo- second order kinetics plot for the adsorption of Remazol Red on saw dust at $25^{\circ} \mathrm{C}$. 
Theoretical and experimental data for the adsorption kinetics are given in table 4 . The experimental values of $\mathrm{q}_{\mathrm{e}}$ are closer to the calculated values for second order kinetics than those of first order kinetics. The value of correlation coefficient $\left(\mathrm{R}^{2}\right)$ for second order is also closer to unity as compared to that of first order (Table 4). Therefore, the adsorption of selected dye on rice husk, sawdust and charcoal, more appropriately followed pseudo second order kinetic model.

Table 4. Kinetic parameters for the adsorption of remazol red on sawdust.

\begin{tabular}{llccclc}
\hline \multicolumn{2}{c}{$\begin{array}{c}\text { Pseudo first order kinetic } \\
\text { model }\end{array}$} & $\begin{array}{c}\mathrm{q}_{\mathrm{e}} \text { exp. } \\
\mathrm{mg} / \mathrm{g}\end{array}$ & \multicolumn{3}{c}{$\begin{array}{c}\text { Pseudo second order kinetic } \\
\text { model }\end{array}$} & \\
\hline $\mathrm{q}_{\mathrm{e}}$ & $\mathrm{K}_{1}$ & $\mathrm{R}^{2}$ & & $\mathrm{q}_{\mathrm{e}}$ & $\mathrm{K}_{2}$ & $\mathrm{R}^{2}$ \\
$(\mathrm{mg} / \mathrm{g})$ & $\left(\mathrm{h}^{-1}\right)$ & & & $(\mathrm{mg} / \mathrm{g})$ & $(\mathrm{h}, \mathrm{g} / \mathrm{mg})$ & \\
& 2.62 & 0.83 & 2.36 & 2.73 & 0.092 & 0.96 \\
\hline
\end{tabular}

\section{Conclusion}

In the present investigation activated saw dust was found to be better adsorbent for the removal of Remazol Red from aqueous media as compared to commercial charcoal. Adsorption of the investigated dye decreases with the increase in $\mathrm{pH}$ and slightly increases with temperature of the solution. It was observed that adsorption process followed pseudo-second order kinetic model. Values of $\mathrm{q}_{\mathrm{e}}$ calculated from pseudo second order plots are in good agreement with the experimental values. Future investigations should be conducted with a view to selectively separating the present dye contaminants, regenerating the exhausted biomass, recovering the sorbed dye and designing to continuous dye treatment systems. These studies can further ameliorate the economic aspects of dye wastewater treatment which will get better opportunity for the water related pollution remediation in pharmacology.

\section{References}

Ahmadpour, A. and Do, D.D. 1997. The preparation of activated carbon by chemical activation. Carbon. 35, 1723-1732.

Arivoli, S., Hema, M., Parthasarathy, S. and Manju, N. 2010. Adsorption dynamics of methylene blue by acid activated carbon. J. Chem. Pharm. Res. 2, 626-641.

Baughman, G.L. and Perenich, T.A. 1988. Fate of dyes in aquatic systems: I. Solubility and partitioning of some hydrophobic dyes and related compounds. Environ. Toxico. Chem. 7, 183-199.
Cotoruelo, M.L., Marques, M.D. and Rodriguez, J.J. 2007. Adsorption of aromatic compounds on activated carbons from lignin: Equilibrium and thermodynamic study.Ind. Eng. Chem. Res. 46, 4982-4990.

Dee, A.K. Environmental Chemistry. 2006. $6^{\text {th }}$ ed. New Delhi: New age International (P) Ltd. p. 208.

Hassan, S.M.S., Awwad, N.S. Aboterika, A.H.A. 2009. Removal of synthetic reactive dyes from textile wastewater by Sorel's cement. J. Hazard. Mater. 162, 994-999.

Ho, Y.S., Chiu, W.T. and Wang, C.C. 2005. Regression analysis for the sorption isotherms of basic dyes on sugarcane dust, Bioresour. Technol. 96, 1285-1291.

$\mathrm{Hu}$, Q.H., Qiao, S.Z. and Haghseresht, F., Wilson, M.A. and Lu, G.Q. 2006. Adsorption study for removal of basic red dye using bentonite. Ind. Eng. Chem. Res. 45, 733-738.

Jain, R., Sharma, N. and Radhapyari, K. 2009. Electrochemical treatment of pharmaceutical azo dye amaranth from waste water. J. Appl. Electrochem. 39, 577-582

Mohanty, K., Naidu, J.T., Meikap, B.C. and Biswas, M.N. 2006. Removal of crystal violet from waste water by activated carbons prepared from rice husk. Ind. Eng. Chem. Res. 45, 5165-5171.

Mon, J. 2004. Sorption and its Effects on Transport of Organic Dyes and Cesium in Soils. Ph.D. Thesis, Washington State University, USA, pp. 28-36.

Ozacar M. and Singel, A. 2005. Adsorption of metal complex dyes from aqueous solutions by pine sawdust. Bioresour. Technol. 96, 791-795.

Rabolli, V., Thomassen, L.C., Princen, C., Napierska, D., Gonzalez, L., Kirsch-Volders M., Hoet, P.H., Huaux, F., Kirschhock, C.E., Martens, J.A. and Lison, D. 2010. Influence of size, surface area and microporosity on the in vitro cytotoxic activity of amorphous silica nanoparticles in different cell types. Nanotoxicology 4, 307-318.

Rao, M.M., Rao, G.P.C., Seshaiah, K., Choudary, N.V. and Wang, M.C. 2008. Activated carbon from Ceibapentandrahulls, an agricultural waste, as an adsorbent in the removal of lead and zinc from aqueous solutions. Waste Mange. 28, 849-858.

Senthilkumaa, S., Kalaamani, P., Porkodi, K., Varadarajan, P.R. and Subburaam, C.V. 2006. J. Biores. Techn. 97, 1618-1625.

Sousa, M.L. de, Moraes, P.B.de, Lopes, Paulo R.M., Montagnolli, R.N., Angelis, D.de F.de and Bidoia, E.D. 2012. Contamination by Remazol Red Brilliant Dye and its impact in aquatic photosynthetic microbiota. Environ. Magt. Sust. Dev. 1, 129-138.

Waghmode, T.R., Kurade, M.B., Kabra, A.N. and Govindwar, S.P. 2012. Degradation of Remazol Red dye by Galactomycesgeotrichum MTCC 1360 leading to increased iron uptake in Sorghum vulgare and Phaseolus mungo from soil. Biotech. Biopro. Eng. 17, 117-126.

Zollinger, H. 2003. Color Chemistry: Syntheses, Properties, and Applications of Organic Dyes and Pigments, $3^{\text {rd }}$ ed. Switzerland: WILEY-VCH Publication, pp. 432-437 